\title{
NEURAL NETWORK SYSTEM FOR IDENTIFICATION OF NON-DESTRUCTIVE TESTING SIGNALS
}

\author{
Koval A.O. \\ Kharkiv National Automobile Highway University
}

\begin{abstract}
In this article the technique of using neural network algorithms in non-destructive control systems is considered. The block diagram of the neural network system for identification of the safe state of fixed objects is presented. The topology of the radial basis and the recurrent Elman network for the initialization of neural structures is determined. Methods and criteria for training the neural network in the process of non-destructive testing of the object are presented.
\end{abstract}

Key words: non-destructive testing, neural network, training, uncertainty, defect, diagnostics.

\section{Introduction}

The development of the latest nondestructive testing technologies requires new approaches to automate the entire testing process. Today, on the one hand, the requirements for non-destructive testing methods are increasing, and, on the other hand, there are no reliable methods of non-destructive testing with the possibility of identification, clustering of defects and prediction of their occurrence. This is not due to technological problems, but mainly to the lack of generally recognized scientific methods for determining the metrological characteristics of the measuring channels of non-destructive testing systems.

In addition, it should be noted that all operations are carried out manually with the use of specialized programmes and devices, which, in turn, requires highly qualified specialists. Since the defect is determined by the expert, this method is characterized by subjective error. The method is strictly valid for linear systems, and the measuring channel of a non-destructive testing system, when air, cracks, voids and other defects present, may not always be considered linear. The information processing in the specified method assumes that the law of distribution of output signals is normal in practice, but not always. Therefore, the expert method cannot be used without limitations for the detection of defects and has a fairly low reliability.

Hence, the need to identify defects by the methods that would be better than the expert method on some important practice indicators emerges. This research is dedicated to the improvement of such methods.

\section{The analysis of publications}

At present, neural networks in metrology are used to solve the problems of identification of objects of measurement and diagnostics and control in branched measuring information sys- tems. These areas of neural network technology are considered in the works of J. Korbicz, D. Materassi, P.V. Tan [1-2]. In these researches, the defects are detected by comparing the output signals with the input test signal, i.e., by solving the inverse measurement problem. The neural network technologies for solving the inverse problem in these researches are investigated in considerable detail. We will analyse the methods of solving the inverse problem using neural networks.

Thus, the works of J. Korbicz and D. Materassi $[1,2]$ offer the solution of the inverse problem as a problem of statistical estimation, for example, by the criterion of maximum likelihood. In this formulation, a discrete operator approximates the continuous operator, and the functional is defined on a discrete set as a function that is inverted to the likelihood function.

P.V. Tan, G. Millérioux, J. Daafouz, B. Saggin $[3,4]$ also propose a method of statistical regularization for solving an inverse problem. The method requires the knowledge of the laws of distribution of the measured signal and the interference, which is a rather severe limitation.

In the research B. Cessac, C. Gonzalez [5, 6] the inverse problem is considered as compensation of the dynamic components of the measurement error. The problem of the algorithm synthesis for determining the measured realisation of the sensor output signal is considered. The synthesis of the algorithm is made based on the criterion of minimum of the mean square of the error signal with a spectral density centered inside the lower and upper bounds of each frequency. The solutions of filter synthesis problem at non-stationary input random processes and inaccurate impulse response are analysed. However, reducing a priori information and increased errors result in reducing the degree of dynamic error compensation $[7,8,10-13]$. 
Thus, all existing approaches to the identification and prediction of defects in nondestructive testing arecbased the use of test input signals and it is difficult to implement into practice [14-16].

The existing methods of non-destructive testing are sensitive to the formation of an expert knowledge base, which should contain basic knowledge taking into consideration the "aging" of the objects of control [9, 17-21]. These methods cannot be used in close-to-real time. In order to compensate the latter weakness, metrological practices use neural network models, which, however, are not designed for the entire measuring channel of diagnostics.

The disadvantages of existing defect detection methods create the need to develop more efficient, methods for detecting, identifying and predicting defects of controlled objects.

\section{The aim and problem statement}

The aim of the article is to develop the methodology of using neural network algorithms for the classification of defects in non-destructive testing systems. The aim results from the need to automate the systems of non-destructive testing and to increase their informativeness and reliability.

\section{The results of the research and them discussion}

The basic approach for solving difficult formalized problems is based on the use of many neural network experts - a set of neural networks of different architecture with the mechanism of solution integration (associative machine). Hence, a general block diagram of the neural network system for identification of the safe state of unmoving objects was developed (Fig. 1).

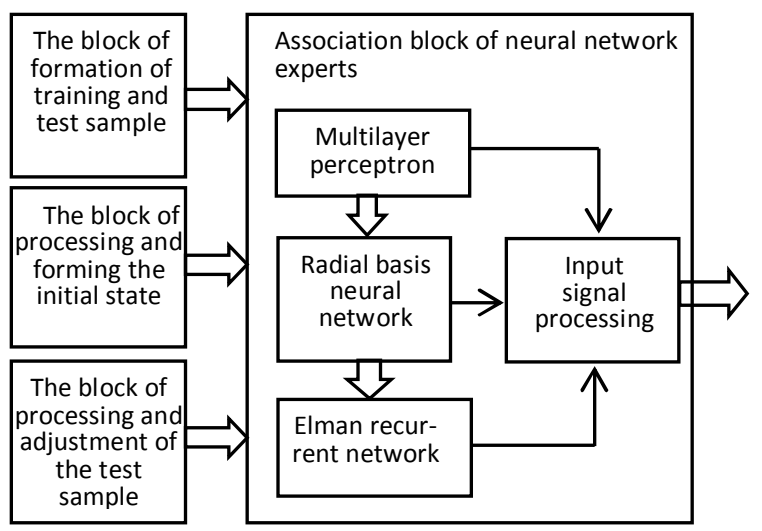

Figure 1. Outline diagram of the neural network identification system of non-destructive control signals
When solving complex problems, there may be a situation when the attempts to obtain a suitable solution, even when using different algorithms that solve a single problem in parallel, do not produce results. In this case, combining multiple algorithms into a composition allows to find a solution to problem. When solving problems with the use of neural network methods built on the use of multiple neural networks of ensembles, the input data are processed using several neural networks. The multilayer perceptron is integrates into the neural network ensemble together with the radial basis neural network and the Elman recurrent network. Each neural network is trained using gradient methods with combined heuristics. The advanced algorithms for training the multilayer perceptron, radial basis network, and Elman recurrent network are presented in Fig. 2-4 respectively. Before the training procedure, all neural network experts need to design their architecture, i.e., make the right choice of the number of layers and elements in each layer. The number of neurons in the input and output layers of all neural network experts is determined by the conditions of the problem under consideration. The number of hidden layers must be selected in terms of the complexity of the dependence that the network must reproduce. For the expert represented by the multilayer perceptron, based on the complexity of the problem being under consideration, three hidden layers were selected. In a radial basis neural network, as well as in the standard model, it is only one hidden layer, which is most often used, and it consists of radial basis neurons. Only one layer of hidden neurons was used in the Elman recurrent network. After the number of layers being determined, it is necessary to select correctly the number of neurons in the hidden layers, and their number is not directly determined by the output of the problem being under consideration. In most cases, the method of simplifying the network structure is inappropriate because networks operate within the committee. The initialization of computational neural structures with resources that far exceed the needs of the computational task leads to complication of experiments. To solve this problem, each neural network expert at the initial stage of the associative machine functioning has a minimum number of neurons in the hidden layers (for multilayer perceptron, the initial number of neurons in the hidden layers is 5 , for the radial basis network it was determined by the $\mathrm{k}$ means clustering procedure, Elman network - 4 neurons). 


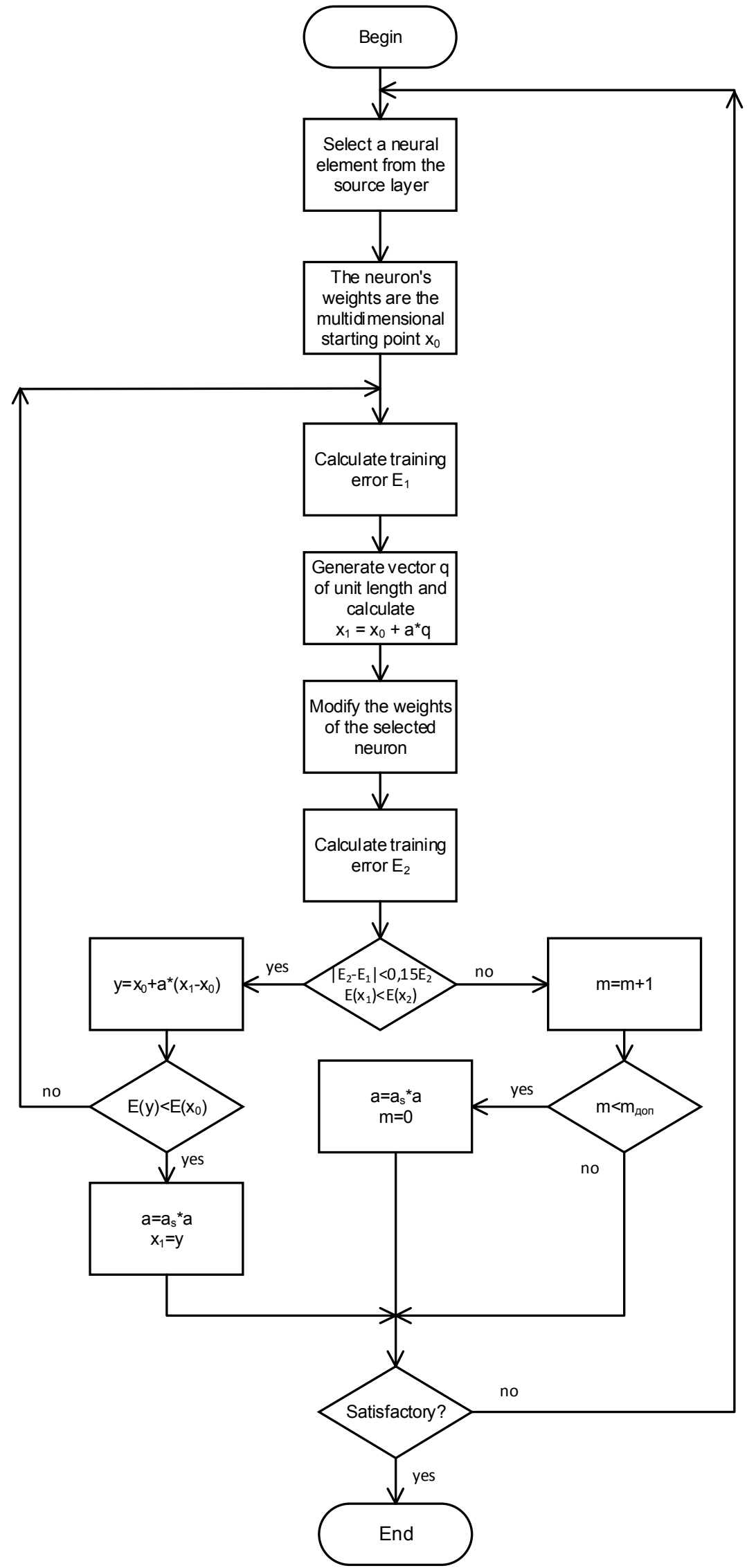

Figure 2. Learning algorithm using heuristic procedures for multilayer perceptron 


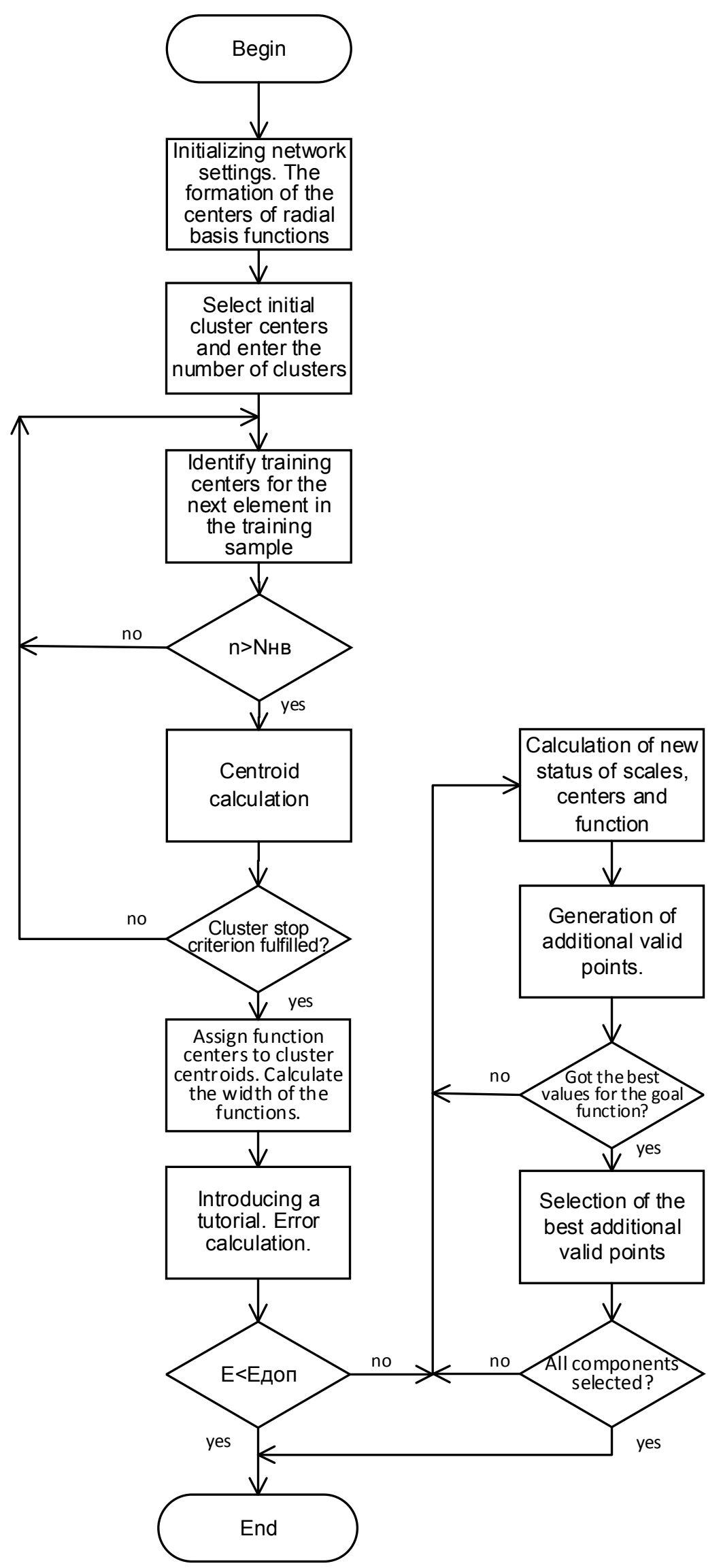

Figure 3. Algorithm of training using heuristic procedure for radial basis function 


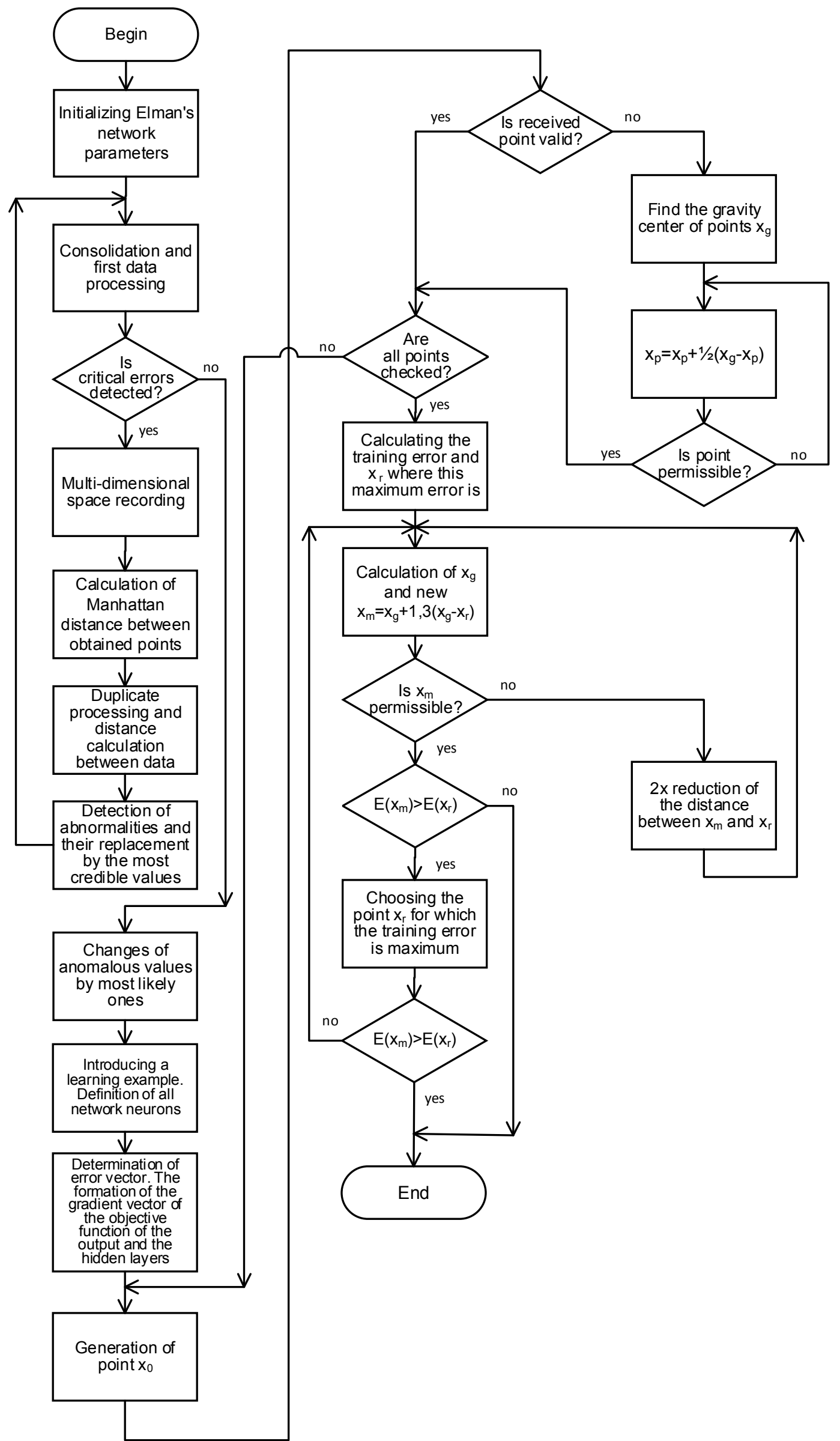

Figure 4. Training algorithm for the Elman neural network 
After predefining the architecture of all networks, the gradual addition of neurons to the hidden layers of the network was performed until the required minimum standard error of training was achieved.

Having determined the topology of neural networks, the training methods are applied. Gradient-based network training algorithms are applied as long as the training error difference for two adjacent iterations is greater than some limit, if the error change value falls below a predetermined limit, then, heuristics are applied. The possibility of using heuristics decreased as the network training process evolved, so that at the initial stage of the training it would prevent it from reaching the local minimum and allow more detailed adjusting of the network parameters at the final stages. We will consider three groups of neural network training algorithms: genetic selection algorithms, gradient descent algorithms, back error propagation algorithm. The algorithms using gradient descent methods. The task of training the network in the case of applying gradient algorithms is considered as the task of minimizing an a priori defined objective function $\xi(w)$. Gradient methods are related to the decomposition of the objective function $\xi(w)$ into the Taylor series in the nearest vicinity of the point of the available solution $w$. In the case of the target function of many variables $\quad w=\left[w_{1}, w_{2}, \ldots, w_{n}\right]^{T}, \quad$ this representation associates with the circle of the predetermined point (at the start of the algorithm, it is the starting point $w_{0}$ ) in the direction $x$. Such decomposition is described by the universal formula:

$$
\begin{aligned}
\xi(w+x)= & \xi(w)+[p(w)]^{T} \cdot x+ \\
& +\frac{1}{2} \cdot x^{T} \cdot H(w) \cdot x+\ldots
\end{aligned}
$$

where $p(w)=\nabla \cdot \xi=\left[\frac{\partial \xi}{\partial w_{1}}, \frac{\partial \xi}{\partial w_{2}}, \ldots, \frac{\partial \xi}{\partial w_{n}}\right]^{T}$ is the vector of the gradient and the symmetric square matrix

$$
H(w)=\left[\begin{array}{ccc}
\frac{\partial^{2} \xi}{\partial w_{1} \partial w_{1}}, \ldots, & \frac{\partial^{2} \xi}{\partial w_{1} \partial w_{n}} \\
\ldots & \ldots & \ldots \\
\frac{\partial^{2} \xi}{\partial w_{1 n} \partial w_{1}}, \ldots, \frac{\partial^{2} \xi}{\partial w_{n} \partial w_{1 n}}
\end{array}\right]
$$

is a second-order derivative matrix, and it is called hessian.

$X$ is used as a guide vector, which depends on the actual values of the vector $w$. In practice, the first three members of the series are more often calculated, and the following are simply ignored. To simplify the description of the values of the variables obtained in the $k$ cycle, they will be written with the lower index $k$. Will consider $w=w_{k}$ the point of solution at which the equality $p\left(w_{k}\right)=0$ and minimum of the objective functions $\xi(w)$ is reached and the hessian $H(w)$ is non-negatively defined. Under these conditions, the function at any point near $w_{k}$ will be more important than at point $w_{k}$, so point $w_{k}$ is a solution that meets the criterion of minimization of the objective function.

In the process of the minimum value of the objective function searching, the search direction $p$ and step $h$ are selected so that a condition $\xi\left(w_{k+1}\right)<\xi\left(w_{k}\right)$ is fulfilled for each subsequent point $w_{k+1}=w_{k}+\eta_{k} \cdot x_{k}$. The minimum is being searched until the gradient norm falls below the a priori set point of the permissible error, or until the maximum number of iterations is exceeded. The universal optimization algorithm for training a neural network can be represented in the following form (we assume that the initial value of the optimized vector is known and equaled $\left.w_{k}=w_{0}\right)$.

Step 1: The convergence and optimality check of the current value $w_{k}$. If point $w_{k}$ corresponds to the gradient conditions of stopping the process, the calculation is completed. Otherwise, go to step 2.

Step 2: The determination of the optimization direction vector $x_{k}$ for point $w_{k}$.

Step 3: The selection of the step size $\eta_{k}$ in direction $x_{k}$ in which condition $\xi\left(w_{k}+\eta_{k} \cdot x_{k}\right)<\xi\left(w_{k}\right)$ is met.

Step 4: The determination of the new solution $w_{k+1}=w_{k}+\eta_{k} \cdot x_{k}$ and its corresponding values $\xi(w)$ and $p\left(w_{k}\right)$, and, if necessary, $H\left(w_{k}\right)$ and return to step 1 .

The conjugate gradient algorithm. This algorithm differs from the general gradient descent algorithm in the fact that hessian information is not used when choosing the minimization direction. Search direction $x_{k}$ is 
chosen in such a way that it is orthogonal and conjugated to all previous directions $x_{0}, x_{1}, \ldots, x_{k-1}$. Set of vectors $x_{i}, i=0,1,2, \ldots, k$ will be mutually conjugated to matrix $\mathbf{A}$ of coefficients of connection between the $i$ juncture of $(L-1)$ layer or the $k$ juncture of the $i$ i layer if

$$
x_{i}^{T} \cdot \mathbf{A} \cdot p_{j}=0, \quad i \neq j,
$$

The vector that satisfies the given conditions looks like:

$$
x_{k+1}=x_{k}+\alpha_{k} \cdot p_{k},
$$

where $p_{k}=p\left(w_{k}\right)$ is the actual value of the gradient vector.

Formula (4) means that the new minimization direction depends only on the value of the gradient at solution point $w_{k}$ and on previous search direction $p_{k}$ multiplied by conjugation coefficient $\alpha_{k}$.

Error back propagation algorithm. In general, the back propagation algorithm represents the following sequence of steps:

Step 1: Initiate scales with small random variables.

Step 2: If the stop condition is not met, follow steps 3-10.

Step 3: Follow steps 4-9 for each training pair.

Direct passage:

Step 4: Each input neuron $x_{i}=1 \ldots . n$ receives the input signal and propagates it to all the hidden layer neurons.

Step 5: Each hidden layer neuron $v_{j}=1 \ldots q$ sums its weighted input signals

$$
h_{j}=\sum_{i=1}^{n} w_{i j} \cdot x_{i},
$$

and applies the activation function to the number obtained, generating an output signal $v_{j}=f\left(h_{j}\right)$, which is sent to all neurons in the output layer.

Step 6: Each output neuron $y_{k}, k=1,2, . ., m$ sums the weighted signals

$$
h_{k}=\sum_{j=1}^{q} w_{j k} \cdot x_{j}
$$

forming after using activation function the output signal of the network: $y_{k}=f^{\prime}\left(h_{k}\right)$.

Back error propagation:

Step 7: Each output neuron matches its output value with the desired objection function and calculates $\delta_{k}=\left(t_{k}-y_{k}\right) \cdot f^{\prime}\left(h_{k}\right)$, after which the correcting term of the weights is determined $\Delta w_{j k}=\eta \cdot \delta_{k} \cdot v_{j}$, and the parameters $\delta_{k}$ are sent to the neurons of the hidden layer.

Step 8: Each hidden layer neuron $v_{j}$ sums up its $\delta$ inputs from the neurons of output layer

$$
h_{k}=\sum_{k=1}^{m} w_{j k} \cdot \delta_{k}
$$

the result is multiplied by a derivative of the activation function to determine $\delta_{j}$ :

$$
\delta_{j}=f^{\prime}\left(h_{j}\right) \cdot \sum_{k=1}^{m} w_{j k} \cdot \delta_{k}
$$

and the correcting term is calculated:

$$
\Delta w_{i j}=\eta \cdot \delta_{k} \cdot w_{j k} .
$$

Weight adjustment:

Step 9: The weights between the hidden and the output layers are modified as follows:

$$
w_{j k}(\text { new })=w_{j k}(\text { old })+\Delta w_{j k} .
$$

The weights between the input and hidden layers are similarly adjusted:

$$
w_{i j}(n e w)=w_{i j}(\text { old })+\Delta w_{i j} .
$$

Step 10: The stop condition is checked: minimization of the error between the required and actual network output. Using the flowchart, the algorithm can be represented as follows (Fig. 5).

The training stopping criterion of the neural network in the identification process of nondestructive control signals. In the process of determining the parameters of the signals of non-destructive control systems using a neural network, the task arises to automatically determine the degree of the similarity of the measured signals, i.e., to determine the metric (the distance between the signals). 


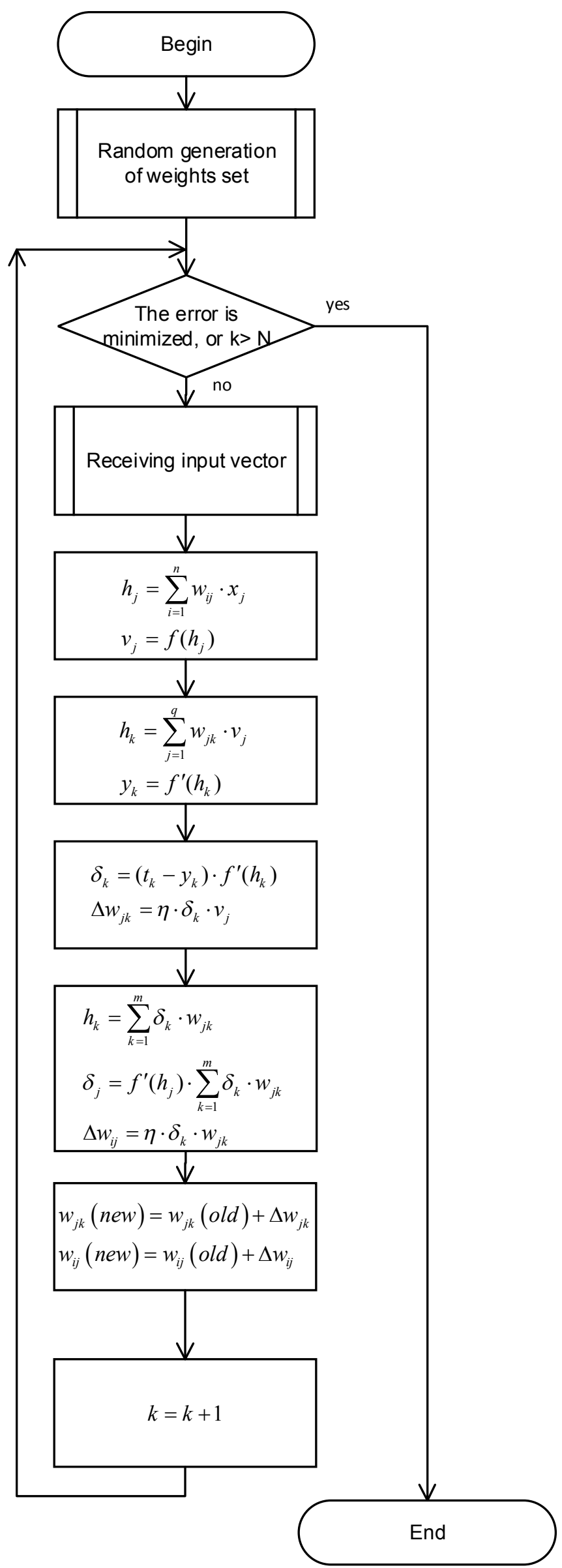

Figure 5. The flowchart of the back error propagation algorithm 
The simplest class of metric comparisons of signals at the output of a device is the comparison of the measured signals by their shape for each time point. For example, the maximum deviation of the signal amplitudes can be compared, but such a metric is sensitive to individual differences in the signal amplitudes

$$
U=\max _{i}\left|a_{i}-b_{i}\right|,
$$

where vectors $a_{i}$ and $b_{i}$ are the values of the amplitudes of the compared input (signals).

Another criterion for an estimation can be the root mean square deviation of the signal amplitudes:

$$
\sigma_{u}=\sqrt{\frac{\sum_{i=1}^{n}\left(a_{i}-b_{i}\right)^{2}}{n}},
$$

where $n$ is the number of measurements in the time sample of the input signal. The disadvantages of this method are:

- high sensitivity to the average difference of the signals in the amplitude, which can lead to an erroneous result in the case the signals are slightly different in the mean in the amplitude;

- the non-destructive testing device has different sensitivity to the distortion of the input signal in different parts of the frequency range, which is related to the amplitude-frequency response of the measuring channel.

It means that the distortion of the compared non-destructive control signals at low $(0,01-$ $5 \mathrm{~Hz})$ and midrange $(5-20 \mathrm{~Hz})$ will be greater than at high $(20-50 \mathrm{~Hz})$. Thus, this metric cannot consider the different sensitivity of the device in different frequency bands, and when comparing two different signals with white noise will most likely conclude that, they are completely different.

Another approach is the frequency-time metric of the inputs of the non-destructive testing device. To obtain this metric, the input signals are first sequentially covered at small intervals with some step $\Delta t$ in time and $\Delta f$ frequency. At each of these intervals, the signal is decomposed into a Fourier series, after which a spectrum is constructed (without taking into account the frequency phase components). The obtained spectra are recorded in a twodimensional array (time, frequency) - the spectrogram.
This metric can be compare with the values of the amplitudes of the signals according to the data of the perception by the device of one or another frequency component, i.e., to make a comparison by the formula

$$
\sigma_{u}=\frac{\sqrt{\sum_{j=1}^{N_{f}} \frac{1}{\alpha_{j}} \cdot \sum_{i=1}^{N_{t}}\left(S a_{j i}-S b_{j i}\right)^{2}}}{N_{f} \cdot N_{t}},
$$

where $S a_{j i}, \quad S b_{j i}$ are two-dimensional amplitude arrays of the spectrograms of two input signals $a$ and $b ; N_{f}, N_{t}$ is the number of the elements of analysis according to frequency and time.

Coefficient $\alpha_{j}$ depends on the sensitivity of the measuring channel in the given $j$ frequency range of the amplitude-frequency characteristic of the non-destructive testing device, the values for which are obtained experimentally.

For this method, as well as for the amplitudetime metric, it is also necessary that the signals should contain equal energy, that is, the root mean square deviation in the spectra for the whole signal should be minimal. If compared to the usual metric, the problem of comparing signals with different amplitudes is practically solved and the non-uniform sensitivity of nondestructive devices to different frequency components is considered.

To test this method of determining the metric of the input signals, it is more correct to apply the modification of this method: several $k$ frequency bands are sequentially allocated from the spectrogram and they determine the standard deviation. The chosen frequency bands are of different widths because the content information for the technological process within $0 \ldots 5 \mathrm{~Hz}$ is greater than in the range from 20 to $40 \mathrm{~Hz}$, and therefore, the bands in the low-frequency range are selected narrower than those in the highfrequency one. Therefore, bandwidth $\Delta f$ in the range from 0,01 to $40 \mathrm{~Hz}$ changes from $\Delta f_{\min }=0,05 \mathrm{~Hz}$ to $\Delta f_{\max }=5 \mathrm{~Hz}$. Accordingly, the number of elements of analysis $N_{f}$ for each

$$
k \text { frequency band } N_{f}=\frac{f_{\max _{k}}-f_{\min _{k}}}{\Delta t_{k}} \text { will }
$$

change too. So, the expression (14) will take the form: 


$$
\sigma_{k}=\frac{\sqrt{\sum_{j=1}^{N_{f}} \sum_{i=1}^{N_{t}}\left(S a_{j i}-S b_{j i}\right)^{2}}}{N_{f} \cdot N_{t}} .
$$

The advantage of this method is possibility of comparing the input signals of the diagnostic equipment processed by the low-pass filter to reduce the amount of measurement information. Such signals can only be compared in the frequency bands that are special for the steady state operation of the controlled object. In addition, in this case, it is not necessary to store the energy of the signals throughout the frequency range when switching from one constant mode of the controlled object to another. With the correct energy conservation of the signal in the frequency band, it is possible to determine precisely the average difference of the signals in this band. One of the disadvantages of the method is the low resolution in both frequency and time.

To reduce the impact of this disadvantage on the performance of the neural network, the entire frequency range input is divided into several $n$ bands. Depending on their importance for the process characteristics and the accuracy of measuring the parameters of the diagnostic signals, the width of each band $d F_{n}$ is different. Similarly, the entire time interval of the analysis of the similarity of the input signals is divided into $m$ sub-intervals of time with different widths $d F_{m}$, within which the comparisons of the signals will be carried out. Thus, it is possible to obtain the average deviation between input signals in size range $n \times m$ :

$$
\sigma_{n m}=\frac{\sum_{j=1}^{N_{f}} \sum_{i=1}^{N_{t}}\left|S a_{j i}-S b_{j i}\right|}{d F_{n} \cdot d T_{m}} .
$$

From the point of view of the extremum search, it is more convenient to estimate not the minima $\sigma_{n m}$ but the maxima $1 / \sigma_{n m}$. The analysis of the metric of the restored signal by the neural network algorithm and the reference input signal by the criterion of the maximum $1 / \sigma_{n m}$ makes it possible to determine the parameters of the signal of non-destructive control in the field of analysis.

The non-destructive testing devices output signal is characterized by several frequency components. The number of these components is different for each continuous operation of the control object. The presence of amplitude and frequency fluctuations both within one and during the transition to another stable mode of the object is distinctive. These fluctuations, at first sight, are not significant, but this leads to the fact that the metric $\sigma_{n m}$ of the compared input actions (their actual energy) will be distributed in several elements of the analysis, which greatly complicates the search for the extremum $1 / \sigma_{n m}$. Consequently, the time and error of learning a neural network increase, in some cases the neural network cannot train at all. To eliminate this disadvantage, the determination of the metric of the input actions to be analysed must be done in three stages.

At the first stage, a sliding slice in the plane "time-frequency" conducts a rough search for the extremum. When found, the exact determination of the elements of the analysis is carried out by simultaneous time-and-frequency analysis in the time and frequency gates - the second stage. Initially, all the maxima that got to the strobe are evaluated simultaneously, and if by the results of the rough estimation the highest maximum is really found, then the frequency strobe further refines it. Since the output signal has fluctuations in both amplitude and frequency, it is necessary to clarify the location of the maximum relative metric within the two adjacent elements of the field "time-frequency" - the third stage. This approach eliminates the ambiguity of the neural network training stop criterion.

\section{Conclusion}

The proposed approach to the automation of the systems of non-destructive testing with the implementation of neural network technologies is practically valuable. The detection, identification, classification and prediction of the defects of objects controlled by the neural network will significantly improve the reliability of diagnostics and constantly expand the knowledge base of defects. The implementation of nondestructive testing of neural network methods will significantly reduce the uncertainty of decision making in the process of flaw detection.

\section{References}

1. Kuş J., Korbicz J. Artificial neural networks in fault diagnosis of dynamical // Diagnostics of Processes. - 2013. - P. 37-49.

2. Materassi D. Reconstruction of topologies for acyclic networks of dynamical systems // Proc. of the American Control Conference. - 2014. P. 37-41.

3. Tan P.V., Millérioux G., Daafouz J. A contribu- 
tion to the identification of switched dynamical systems over finite fields // Proc. 49th IEEE Conference on Decision and Control. - 2013. P. 4429-4434.

4. Saggin B., Debei S., Zaccariotto M. Dynamic error correction of a thermometer for atmospheric measurements // Measurement. - 2015. 30. P. 223-230.

5. Cessac B. Neural Networks as dynamical systems // International Journal of Bifurcations and Chaos. - 2014. - № 6. - P. 1585-1629.

6. Gonzalez C. Instance-based learning: integrating sampling and repeated decisions from experience // Psychol. Rev. - 2015. - № 118. - P. 523551.

7. Jia F., Lei Y., Lin J., Zhou X., Lu N. (2016). Deep neural networks: A promising tool for fault characteristic mining and intelligent diagnosis of rotating machinery with massive data. Mechanical Systems and Signal Processing, 72-73, 303315. https://doi.org/10.1016/j.ymssp.2015.10.025

8. Aldrich C., Auret L. (2013). Unsupervised Process Monitoring and Fault Diagnosis with Machine Learning Methods. London: Springer London. https://doi.org/10.1007/978-1-4471-5185-2.

9. Kondratenko A., Boikov I., Marenko H., Tsebriuk I., Koval O., Koval A. Method of protecting specially important objects based on the application of the bistatic radiolocation technique. EUREKA: Physics and Engineering. 31 July 2019. Vol. 4. P. 63-75. DOI 10.21303/2461-4262.2019.00941.

10. Scardapane S., Panella M., Comminiello D., Uncini A. Learning from distributed data sources using random vector functional-link networks: Procedia Computer Science. Elsevier B.V., 2015. P. 468-477.

11. Umamaheswari R. Trends in non-stationary signal processing techniques applied to vibration analysis of wind turbine drive train A contemporary survey. 2017. ISBN 0888-3270.

12. Maropoulos P. G., Guo Y., Jamshidi J. Cai B. Large volume metrology process models: A framework for integrating measurement with assembly planning. CIRP Annals Manufacturing Technology [online]. 2008. Vol. m, no. 1. P. 477480. Available from: http://dx.doi.org/10.1016/j.cirp.2008.03.

13. Materka A., Mizushina S. Parametric signal restoration using artificial neural networks. IEEE Transactions on Biomedical Engineering. 1996. Vol. 43, no. 4. P. 357-372. DOI 10.1109/10.486256.

14. Anzo A., Barajas-Ramírez J.G. A coevolution model for dynamical networks of discrete-time chaotic systems: IFAC Proceedings Volumes (IFAC-PapersOnline). $2012 . \quad$ ISBN 9783902823021.

15. Scardapane S., Panella M., Comminiello D., Uncini A. Learning from distributed data sources using random vector functional-link networks: Procedia Computer Science. Elsevier B.V., 2015.
P. 468-477.

16. Sastry P.S., Santharam G., Unnikrishnan K.P. Memory neuron networks for identification and control of dynamical systems. IEEE Transactions on Neural Networks [online]. 1994. Vol. 5, no. 2. P. 306-319. DOI 10.1109/72.279193. Available from:

http://www.ncbi.nlm.nih.gov/pubmed/18267799

17. Коваль А.О., Полярус О.В. Вплив «старіння» датчиків температури на їх динамічні характеристики. Системи обробки інформащії. 2014. Вип. 6. С. 123-126.

18. Коваль А.О. Прогнозування метрологічної надійності датчиків тиску на техногеннонебезпечних об'єктах. I Всеукраӥнська наук.тех. конф. «Актуальні проблеми автоматики та приладобудування»: тези доп. ННЦ «Інститут метрології» (м. Харків, 23 березня 2014 р.). Харків: ННЦ «Ннститут метрології», 2014. C. 79-83.

19. Полярус О.В., Коваль А.О. Використання методу шумів та online діагностики для вдосконалення метрологічного забезпечення на техногенно небезпечних об'єктах. Вісник НТУ «ХПІ». Харків, 2015. № 35. С. 152-156.

20. Коваль А.О., Коваль О.А. Просторово розподілені інтелектуальні вимірювальні інформаційні системи: монографія. Харків: Лідер, 2017. 146 с.

21. Коваль А.О., Чайка В.В. Прогнозування метрологічної надійності датчиків тиску. Всеукрайнська науково-практичної конферениій здобувачів вищої освіти $і$ молодих учених «Метрологічні аспекти прийняття рішень в умовах роботи на техногенно небезпечних об 'єктах»: тези доп. ХНАДУ (м. Харків, 30 березня 2019 р.). Харків, С. 72-75.

Andrii Koval, $\mathrm{PhD}$ (Tech), associate Professor, Department of Metrology and life safety, tel: (+380)-68-606-20-68, e-mail: koval_andrey79@ukr.net, ORCID ID: https://orcid.org/0000-0001-6819-6423. Kharkiv national automobile and highway University, 25, Yaroslava Mudrogo str., Kharkiv, 61002, Ukraine.

\section{Нейросетевая система идентификации сигна- лов неразрушающего контроля}

Аннотация. Рассмотрена методика использования нейросетевых алгоритмов в системах неразрушающего контроля. Приведена структурная схема нейросетевой системь идентификации сигналов дефектоскопии неподвижных объектов. Определена топология радиальнобазисной и рекурентной сети Эльмана для инициализациии нейросетевых структур. Приведены методы и критерии обучения нейронной сети в процессе неразрушающего контроля объекта.

Ключевые слова: неразрушающий контроль, нейронная сеть, обучение, неопределенность, дефект, диагностика. 
Коваль Андрей Александрович, к.т.н., доцент кафедры метрологии и безопасности жизнедетельности, тел. (+380)-68-606-20-68, e-mail: koval andrey79@ukr.net, ORCID ID: https://orcid.org/0000-0001-6819-6423. Харьковский национальный автомобильнодорожный университет, 61002, Украина, г. Харьков, ул. Ярослава Мудрого, 25.

Нейромережна система ідентифікації сигналів неруйнівного контролю

Анотація. Проблема. Аналіз сучасних систем неруйнівного контролю показав, щуо в них відсутні як ідентифікація $і$ класифікачія виявлених дефектів, так $i$ прогнозування їх розвитку. Цей недолік можна усунути, якщо в режимі реального часу за даними поточного контролю за допомогою інтелектуальної інформаційної системи неруйнівного контролю класифікувати й оцінювати технічний стан об'єкта контролю. Одним з варіантів розв'язання цฺього завдання $\epsilon$ використання нейромережної системи неруйнівного контролю. Мета - обгрунтувати методику використання нейромережних алгоритмів у системах неруйнівного контролю. Мета обумовлена необхідністю автоматизаиії систем неруйнівного контролю та підвищення $\ddot{x}$ інформативності та достовірності. Методологія. Результати отримані на основі всебічного аналізу результатів застосування множини нейромережних експертів - сукупності нейронних мереж різної архітектури 3 механізмом об'єднання рішень (асоиіативна машина). Завдання на дослідження полягає в розробленні та всебічному аналізі нейромережних структур інтелектуальних систем неруйнівного контролю. Результати. Проведені дослідження дозволили визначити топологію радіальнобазисної та рекурентної мережі Ельмана для ініціалізації нейронних структур. Визначено критерій зупинки навчання нейронної мережі за умови ідентифікачії сигналів систем неруйнівного контролю. Таким критерісм обрана метрика (відстань між сигналами). За результатами досліджень із всієі сукупності метрик обрана частотно-часова метрика. Було встановлено, що в процесі використання частотно-часової метрики критерієм зупинки навчання нейронної мережі за умови ідентифікаиії сигналів систем неруйнівного контролю не обов'язково зберігати енергію тестових сигналів у всьому частотному діапазоні в разі переходу від одного сталого режиму об'єкта діагностики до іншого. 3 метою збільшення розрізнювальної здатності иьього методу як за частотою, так $і$ в часі запропоновано використовувати смуговий частотний аналіз у межах кожного часового вікна поля аналізу. Мінімум середнього відхилення між вхідними сигналами системи неруйнівного контролю в області розміром був прийнятий як критерій зупинки навчання нейронної мережі. Неоднозначність оцінки критерію зупинки навчання нейронної мережі усувається методом уточнення місиерозташування екстремуму в межах двох сусідніх елементів поля аналізу «час-частота». Орихінальність. Уперше було застосовано методологію метрики сигналів неруйнівного контролю для покращення навчання нейронної мережі системи ідентифікаиії дефектів об'єктів контролю. Практичне значення. Отримані результати можуть бути використані для розроблення інтелектуальних систем неруйнівного контролю.

Ключові слова: неруйнівний контроль, нейронна мережа, навчання, невизначеність, дефект, діагностика.

Коваль Андрій Олександрович, канд. техн. наук, доцент кафедри метрології та безпеки життєдіяльності, тел. (+380)-68-606-20-68, e-mail: koval andrey79@ukr.net, ORCID ID: https://orcid.org/0000-0001-6819-6423. Харківський національний автомобі-льнодорожній університет, 61002, Україна, м. Харків, вул. Ярослава Мудрого, 25. 